\title{
Quality and Productivity of Teachers in Selected Public Secondary Schools in Kenya
}

\author{
Maina Moses Ndugu \\ School of Education, Mount Kenya University \\ Email: mainamosesn@gmail.com
}

\section{Doi:10.5901/mjss.2014.v5n5p}

\section{Abstract}

According to the Ministry of Education, science and Technology (MOEST) report of the third Teacher Education Conference in Njoro (1995) the teacher's productivity/performance heavily depends on a number of factors including professional training, attitude, academic background and the education infrastructure of the Institution as well as staff development programmes that are in place at a given time. According to data obtained from Murang'a District Education Office (District Education Office) teaching of sciences is likely to be wanting as reflected in the poor performance of students in KCSE results of 2006. Teacher productivity was measured in terms of student academic performance. It's upon such a background that this study was conducted to explore teacher factors that could be responsible for the poor academic performance of students in Kamacharia Division, Mathioya District, Kenya.

Keywords: Education, Quality, Performance, Teachers, Productivity

\section{Introduction}

Kenya Educational system has expanded significantly since independence. Secondary education has played a significant role in supplying man power needed for economic growth and development in Kenya by creating a class of educated leaders. Planners expect secondary schools and institutions of higher learning to produce the critically needed middle and higher level man power for enhancement of socio - economic development (herbison and Myers 1964)

This explains why Kenya spends substantial amount of Money in Education. The Government continues to increase resources allocated to Education thus in 2004 / 2005 financial year gross expenditure for Ministry of Education estimated to be kshs. 86,123.14 Million representing an increase of $12.2 \%$ from Kshs. 76,724.78 Million. Higher education accounted for $12 \%$ of the total Expenditure recurrent expenditure for higher education increased by $30.3 \%$ (republic of Kenya 2005)

However, developments can not be achieved without addressing the issue of quality teaching. According to Sifuna (1973) there was an attempt to tackle the problem of the quality of Kenyan teachers as early as 1938 when the Christian Missionaries made a proposal for re organization of primary teachers' training. He further noted that a committee headed by hock hart reported on a design to expand the teacher training. The general feeling was that unless the expansion of the teacher education kept pace with the overall rapid growth in the educational system, there was bound to be a problem with educational standards. Abidha (1983) and Ochanda (1983) also shows the fact that the quality of the teacher determine the success of any educational system and the level of educational performance and achievements in examinations. This view is also upheld by the national Committee on Educational Objectives and policies (Republic of Kenya, 1976, 109), which states "the Qualitative attributes of the teachers are of paramount importance in determining the quality of education in which intellectual developments of the child is based."

In this very event, students' are expected to exhibit high academic integrity in form of good grades from schools and job performance after school. In Kenya, there is a big number of students who complete the primary education level and there are more secondary schools than secondary and tertiary institutions. This means that there are many students who are competing for the few posts in secondary and tertiary institutions which calls for better results if one is to successful compete. In addition to this less than half of secondary schools candidates obtain poor grades to take them to secondary schools and one wonders why (Arudo, 2008).

Despite the many measures put in place to improve students' performance, poor grades at National Exams are still prevalent (Enamiroro, 2010). The blame is put to all the stake holders in education like teachers, parents, school management and government. This indicates that the problem of poor performance of students affects everybody in society, for even the employers now and again cry for poor performance of employees, attribute it to poor training in institutions of learning. Without pinpointing who is who, the problem needs immediate solutions, if the country is to be 
transformed from a third world to a medium level of development.

The Education office noted that while performance in other subjects was above average, that of mathematics and sciences was much below the average. The quality of the teaching force, alongside the completion rates and transition rates, are some of the key determinants of efficiency and effectiveness at any level of Education (MOEST 2000) According to UNESCO (1964), whatever the pattern of teaching may be, the teachers part in it is the most important single factor. Given these views, the researcher intends to examine whether there exists a relationship between teacher quality factors such as experience, qualification, motivations, altitude and contact hours with his productivity in terms of students performance in exams at KCSE level in Kamacharia Division Mathioya district of Kenya. It's upon such a back ground that this study was undertaken given the competence of the researcher in teaching having witnessed the problem of poor performance in his school of study.

\section{Research Design}

The researcher used descriptive correlation survey design to investigate the relation between quality and productivity of teachers in Kamacharia division. A combination of qualitative and quantitative method was used. Descriptive survey research studies are designed to obtain pertinent and precise information concerning the current status of phenomenon and whenever possible to draw valid general conclusion from the facts discovered ( Lokesh ,1984 ). The study took the quantitative approach or paradigm in that it was based on variables measured with numbers and analyzed with statistical procedures (Creswell, 2003). The study was co relational in that it was interested in relating quality to productivity of teachers (Charles, 1995), the study was a survey in that it involved a large number of respondents (Best\&Khan, 1993), and cross sectional in so far as pertinent data was collected from all respondents once and for all to reduce on time and costs involved (Creswell, 2003).

\section{Theoretical Framework on Motivation}

\subsection{Maslow's Hierarchy of Needs Theory}

Maslow believed that people who come out of an environment which does not meet their basic needs, tend to experience psychological complaints later in life. Based on the application of this theory to organisational settings, it can be argued that people who do not meet their needs at work will not function efficiently. Maslow's theory is based on two assumptions; that is: people always want more and people arranged their needs in order of importance (Smith \& Cronje, 1992). Maslow (1970) and Schultz, Bagraim, Potgieter, Viedge and Werner (2003) summarised these needs as:

a. Physiological needs. This is the basic need known as the biological needs such as the need for water, food, rest, exercise and sex. Once these needs are met they no longer influence behaviour. An example of this would be trade unions ensuring that their member's basic needs are met because they negotiate for better wages for their members (Smith \& Cronje, 1992).

b. Safety needs. Once the first need is satisfied then the security needs assume precedence. These include the need for job security, insurance and medical aid and the need to feel protected against physical and emotional harm (Smith \& Cronje, 1992).

c. Social needs. This third level of needs is activated once the second level of needs has been adequately met. People have a need for love, friendship, acceptance and understanding from other people. Employees have a tendency to join groups that fulfil their social needs. Managers can play an important part by encouraging people to interact with one another and make sure that the social needs of subordinates are met (Smith \& Cronje, 1992).

d. Ego and esteem needs. The fourth level of needs is the need for self-respect, recognition by others, confidence and achievement. Supervisors can play an active role in satisfying the needs of their employees by recognizing and rewarding high achievers for good performance (Smith \& Cronje, 1992).

e. Self-actualisation needs. This is the highest level of Maslow's hierarchy of needs, and leads to the full development of a person's potential. It is a need where individuals reach full potential and what they want to be become, to utilize all talents well, and to be creative (Glueck, 1974).

Practicing managers have given Maslow's need theory wide recognition, which they ascribe to the theory's intuitive logic and ease of understanding. However, Robbins et al. (2003), argue that research does not validate the theory, since Maslow does not provide any empirical substantiation, and a number of studies that were seeking validation for the theories have similarly not found support for it. 


\subsection{Hertzberg's Two-Factor Theory}

In terms of Hertzberg's motivation-hygiene theory, factors that make employees feel good about their work, are different from factors that make them feel bad about their work. According to Hertzberg (cited in Schulz et al., 2003), employees who are satisfied at work attribute their satisfaction to internal factors, while dissatisfied employees ascribe their behaviour to external factors. Factors that play a role in contributing to the satisfaction of employees are called motivators, while hygiene factors contribute to job dissatisfaction. These two factors are also called the intrinsic (internal) and extrinsic (external) factors.

Fig 2.1: gives a schematic representation of the two-factor theory.

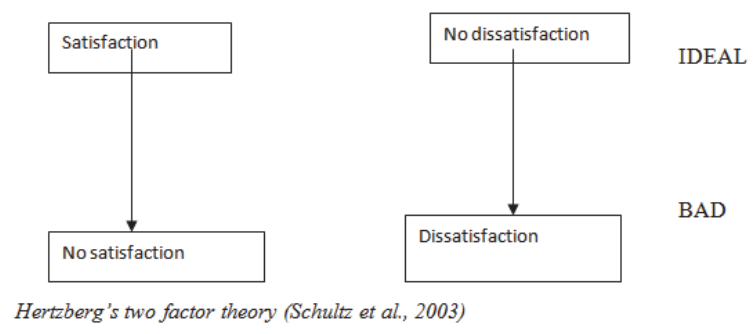

It can be argued that if the hygiene factors are removed, that it is unlikely workers will be satisfied. Both the hygiene factors and motivators play an important role in the performance of the individual. Criticism against Herzberg's theory is that the relationship between motivation and dissatisfaction is too simplistic as well as the relationship between sources of job satisfaction and dissatisfaction (Smith et al. 1992).

\section{Concepts, Opinions, Ideas from Authors/ Experts}

Education reform advocates in the United States and elsewhere frequently argue that, other than the intrinsic rewards of teaching, there exists little or no incentive for teachers to do a good job. (Ballou, 2001). It is very difficult to fire a poorly performing teacher after that teacher has been in a typical public school for a brief probationary period. And most public school teachers are paid on a salary scale, in which a district's salaries are determined entirely by teachers' educational attainment and experience (Ballou, 2001).The practice of uniform pay for teachers of similar educational and experience levels, however, has not always been the norm in the United States. A century ago, incentive systems for teachers were much more common, but the percent of United States school districts using merit pay fell from 48 percent in 1918 to 20 percent in 1939 and just 4 percent in 1953 (Murnane and Cohen (1986).

Amid recent calls for greater use of incentives in government, merit pay plans have spread again. Ballou (2001) reports that they were found in 10 percent of school districts in 1984 and in 12 percent in 1993. In recent years, some states have begun to mandate some notion of merit pay. For example, Florida now requires school districts to earmark a minimum of five percent of the total salary pool to be used for teacher performance awards, and its state board of education recently approved a statewide system of student performance-based merit pay. And recently the Denver school district overhauled their salary schedule to incorporate a large merit pay system.

While there exists considerable research on the factors underlying schools' decisions to implement teacher merit pay plans Ballou and Podgursky (1997); Ballou( 2001) and the stability of these plans Johnson (1986); Murnane and Cohen (1986); Hatry, Greiner, and Ashford (1994), this increased use of teacher merit pay in American education is occurring with virtually no evidence on its potential effectiveness. The closest the empirical literature has come to evaluating the effectiveness of teacher performance incentives in the United States involves school-based incentive systems. Clotfelter and Ladd (1996) and Ladd (1999) studied Dallas's school-based program by comparing the gain in student pass rates in Dallas with those in five other large Texas cities.

They found that pass rates increased in Dallas relative to other cities. But the fact that a positive difference for Dallas was estimated for the year before the scheme was initiated raises questions about these findings. Lavy (2002) carefully matched Israeli schools eligible for a school-based incentive program with schools in similar small communities and found that this program was associated with higher test scores. Glewwe, llias, and Kremer (2003) studied the effects of a schoolbased teacher incentive experiment in rural Kenya, where every teacher in grades 4 to 8 in a winning school 
got the same bonus. The authors show that the specific teacher incentive program introduced in this experiment led to the manipulation of short-run test scores, but no long-term achievement gains among learners, suggesting that participating teachers may have attempted to "game the system."

Although the literature has focused on school-based incentives, most classroom settings involve one teacher, which makes it possible to reward more effective teachers. We know of just one published paper that studied incentive programs for individual teachers. Eberts, Hollenbeck, and Stone (2002), comparing means across two schools, found that individual incentive programs for teachers were associated with a significant fall in drop out rates but were unrelated to student achievement. The only evidence of a correlation between individual incentive programs and student learning is reported in a working paper by Lavy (2003), who found that large teacher incentives in Israel were associated with increases in the tests directly rewarded by the program.

Teachers who spend time preparing lessons and marking homework and class work tend to achieve better result than those who don't (colloids 1989). Government need lift the teachers morale though most cannot afford monetary incentives, but by improving in rewards, career opportunities, initiatives and in service preparations, status and prestige by attracting high quality recruits and retaining talented practitioners in teaching and leadership posts (UNESCO 1994). But teachers hardly spend any time preparing their lessons, they often don't use schemes of work nor do they keep records of work covered by students. Discipline relies too heavily on punishment. (CASTME International Formal of education development 2001; 361 - 374). Otieno (1997) studying the role - overload among secondary school teachers in Nairobi found a significant relationship between role - overload and achievements of learners. He says that job stress is a major factor in low teacher morale, poor performance, absenteeism and high job turnover. Teachers experiencing job stress have low morale and are not in a position to provide quality teaching. Both Female and male workers in human service fields may experience same amount of stress but do cope differently, Malach and Jackson 1978 cited in Otieno (1997). This calls for the investigation on how much the teacher of mathematics is motivated to participate in subject panels, external examination marking, co-curriculum activities, regular teaching, frequent testing, lesson preparation and remedial teaching which facilitate high achievement in examination and consequently quality outputs.

\section{Teacher salary and motivation of teachers}

Previous research (Voydanoff, 1980) has shown that monetary compensation is one of the most significant variables in explaining job satisfaction. Inadequate pay in relation to other occupations is one of the most important factors related to job satisfaction among employees. Olivier and Venter's (2003) research amongst teachers revealed that teachers were most dissatisfied with their salaries, especially taking into account the after-hours input their jobs demand from them and how negatively their salaries compare with those of people in the private sector and other government departments.

Steyn and van Wyk (1999) found in their research amongst urban black schools in South Africa, that the majority of teachers complained of poor salaries. Olivier and Venter (2003) surmise that this provides a feasible explanation why some teachers embark on second jobs, mostly to the detriment of the school and the learners. Others search for alternative propositions and change to completely new jobs for the sake of better incomes.

Good remuneration together with good working conditions has stabilizing effects on labor which may be required. Although it does not work independently, good pay is assumed to give satisfaction to the employee they are paid their value (Maicibi 2005).hence teachers must be properly numerated and provided with good working conditions so that to be motivated to perform better and through which the school performs high. According to Henry (1973) the study of motivation attempts to answer. Why do people behave as they do? When we speak of motivation or in more precise terms, motivation or in more precise terms motivated behaviour having three distinguishing characteristics. first motivated behavior is sustained that is persist for relatively long periods of time second motivated behavior is directed towards the achievement of a goal and third it is behavior resulting from a felt need consequently a school could motivate its teachers and via which it advantages their teachers by providing fair reward and compensated to them.

Compensation administration is the process of determining a cost effective pay structure that will attract and retain competent employees and to provide an incentive for those individuals to exert high energy levels at work (Robbins \&David2001). Accordingly schools could possibly apply compensation administration so as to design a cost effective pay structure for their teachers. Performance is likely to be high when (1) challenging goals are present (2) the moderators (ability goal commitment feedback and task complexity) are present (3) the mediators (direction effort persistence and task are operating (Hellriegel et at, 2001) similarly the educational system would be pursuing smoothly when the three terms on above are harmoniously working in school.

The concept on above helped the researcher to sustainably deal with and find out a solution for the problem. To the researcher when teachers were more motivated. Their school enjoyed higher productivity whereas when not 
productivity would be decreased hence productivity of the school and the teacher's motivation were directly related. Their motivation and their performance were also directly elated in turn if properly managed reward and compensation can lane the teacher's towards good performance and higher motivation.

\section{Teacher Length of Experience and Performance of Students}

Besides the view by Parmay (1979) that there is an efficiency "freeze" by teacher after fifteen years of teaching experience, a study done by Thias and Carnoy (1972) in Kenya show that teacher experience is better predictor of examination performance than is the formal qualification of the teaching staff. They however hasten to add that this may not be due to the accumulated years of experience but probably due to the respect accorded to the older from the young generation in African societies and the fact that senior staffs are rarely transferred compared to the younger staffs.

Bridges (1986) Eshiwani (1986) and Ojwang (1995) from their studies confirmed that students with experienced teacher do better than those with less experienced teacher. Can the government then reverse to training on job and cut training costs to make education more cost effective. But Kyriacou, C (1975)) say experience is more associated with achievement of students only at the Secondary level and further research is necessitated. Conducting this production function with teacher variables will enable me to discover the best combination of teacher characteristics (input) that can be functionally associated with performance (output). In the case of Kenya, the literature review shows that no study has examined the input output relationship at the school level with particular attention to teacher variables. This study tends to fill this gap as well as provision of a rationale for re-training and professional re-orientations services for serving mathematics teachers for the educational planners and ensure cost effectiveness in the education system.

Teachers who have limited teaching experience have a more positive impact on the students' achievement level than senior teachers. Such a conclusion could be attributed to the possibility that teachers who have recently become involved in the teaching career continue to acquire fresher pedagogic and professional knowledge in their educational field. Their competence can also be attributed to their higher enthusiasm for teaching. Some senior teachers are undoubtedly more experienced, but their long, excessive years of teaching the same discipline could have negatively influenced their teaching motivation.

\section{Teacher Qualification and Academic Achievement of Students}

Teachers should have high mastery of subject content by going through formal education, which is beyond the level of his students (Psacharopolous 1985) this is supported by Caillods (1989) who found teachers with more post-secondary education to achieve more with their students than teachers with less post-secondary education.

The economist is much more interested in the relationship between input and output of the school systems as a measure of its productivity and efficiency (Beeby, 1966) school quality can be seen at the level of materials inputs allocated per each school pupil and the level efficiency with which material inputs are organized to raise students' performance (Eshiwan 1993).

The teacher is therefore a central input in the school system whose role on determining achievement needs investigation. Teacher certification and academic qualification are particularly important at upper secondary level (Hopkins, 1997). This view is supported by Guthric J.W (1970) who says that there is a positive association between teacher training variables and standard learning. They are convinced that training teachers do make a difference and that teacher's qualifications, experience and amount of Education and knowledge are truly related to students' achievements. Ojwang (1995) found significant effect of teacher qualification on achievement of students. But Gal, et al (1996) on the other hand revealed zero correlation between teacher qualification and students' examination scores in Kenya, Egypt and Paraguay. Psacharopoulus (1985) also points out those students do almost as well when studying under untrained teacher as they do when studying under trained graduate from University.

Jones (1997) studied the effect of trained and untrained teacher in classroom performance in Barbadoes and established that trained teachers do not have advantage over untrained teachers in classrooms performance. Therefore the need to confirm the effect of training on students' achievement which will help the government to justify the huge expenditure on teachers training. The past studies stress education on qualification but even after achieving almost 100\% teacher training for secondary level, the achievement in mathematics has remained low deteriorated to the detriments of girls.

In the criterion for producing better results in the teaching learning process, Fawns and Nance (1993) state that „teacher knowledge , reason and judgment rather than teaching behaviour should be emphasized as the basis of an account of exemplary teaching". Lafayette (1993) has shown strong correlation between the subject knowledge of the 
language teacher and the learning outcomes. He argues that a sound command of the target language gives the teacher a high degree of confidence to meet the requirements of the learners ultimately affecting their performance. Wilkins (1974) is of the view that a poor command of English language puts the teacher in a critical situation due to the unpredictable nature of the classroom situation. In communicative language teaching the knowledge of the target language is of paramount importance.

Al-Mutawa and Kailani (1989) describe their observation that if the teachers do not have a practical command of the target language, their poor knowledge of the English sound system, grammar and vocabulary, and poor communication skills, will fail them in performing effectively. Cullen (1994) suggests that communicative language teaching methodology requires the language teacher to have higher level of proficiency in the target language. Thus, with changing trends in the teaching learning process result in particular must be a criterion for a successful language teacher.

Proponents of teacher certification standards purport that specific teacher characteristics such as certification and academic major are associated with increased gains in student achievement (Darling-Hammond, 2000). Others declare the available research does not support specific rigorous teacher preparation and certification standards. Two recent works stated that teacher certification requirements do not effect student achievement, but do raise barriers that prevent qualified applicants from entering the profession

In a research conducted by Goldhaber and Brewer (1997), it was found that those mathematics students who received instruction from a teacher with advanced or master"s degrees in mathematics, achieved higher scores as compared to those students whose teachers had no advanced degree or degrees in non-mathematics. One concern regarding underqualified teachers is how well they know the subject matterthat they are assigned to teach. In general, teachers on emergency permits as well as those on alternative certificates may or may not have demonstrated subjectmatter knowledge through a major or minor or through passing a certification test. Many have argued that many fully certified teachers have not demonstrated subject-matter knowledge either because they obtained an education degree rather than a subject-matter degree or because in the past many teachers were not required to pass a subject-matter state examination.

Although one might assume the literature base establishing a positive relationship between a teacher's subjectmatter knowledge and increased student achievement is both voluminous and consistent, Wilson, Floden, and FerriniMundy (2001) found that the research base in this area is, in fact, relatively small and certainly not consistent. Indeed, Wilson et al. stated, "The conclusions of these few studies [on the connection between subject-matter preparation and student achievement] are provocative because they undermine the certainty often expressed about the strong link between college study of a subject matter and teacher quality" (p. 6). In their review, Wilson et al. found only a few studies that examined teacher preparation, subject-matter knowledge, and student achievement that met their rigorous criteria for inclusion in their review.

In general, researchers have found that possessing a major or minor in mathematics or science is related to increased student achievement in these subject areas. Goldhaber and Brewer (2000) found that students with teachers with degrees in mathematics had greater gains in achievement than students with teachers with non mathematics degrees, but the researchers found no such results for science. In a previous study, Goldhaber and Brewer (1996) found that subjectspecific training in mathematics and science has a significant and positive impact on student achievement in these areas. This suggests that greater subject-matter knowledge is associated with gains in student achievement, albeit only in the areas of mathematics and science.

Also with respect to degree level, Ehrenberg and Brewer (1994) found that the percentage of teachers with at least a master's degree was associated with greater achievement for African American students in mathematics, reading, and vocabulary. Likewise, Ferguson (1991) found that the percentage of teachers with master's degrees in Texas was positively associated with student achievement gains at the district level. Alternatively, using Texas data as well, Rivkin, Hanushek, and Kain (2002) stated that master's degrees are not related to teacher effectiveness. However, the authors only examined the scores at the elementary grades.

Again, looking at mathematics, Rowan, Chiang, and Miller (1997) found that students taught by teachers with mathematics major had greater gains in student achievement, although the effect on student achievement was rather small. Likewise, Wenglinsky (2002) found that mathematics and science teachers with an undergraduate minor or major in their field elicited greater gains in student performance. In fact, Wenglinsky noted, "Students whose teachers majored or minored in the subject area that they are teaching outperform their peers by about $40 \%$ of a grade level in both math and science." (p. 7). While not directly investigating the effect of an undergraduate degree, Hawk, Coble, and Swanson (1985) found that students with mathematics teachers assigned in-field and who possessed a major or minor in mathematics scored higher and had greater gains than students with mathematics teacher's assigned out-offield and who did not have a major or minor in mathematics. 
In a comprehensive study, Monk (1994), found that undergraduate coursework in mathematics was positively related to student improvement in mathematics, but that having a mathematics major had no effect or a negative effect on student performance. However, when examining the effect on students by their type of course, Monk found that additional undergraduate mathematics courses did positively impact student achievement for students in advanced courses, but had no effect on student achievement for students in remedial courses.

With respect to the life sciences, Monk found that coursework had no effect on student achievement. With respect to undergraduate coursework in the physical sciences, he found a positive relationship between the number of courses and gains in student achievement. Interestingly, unlike with mathematics, having a science major was positively associated with gains in student achievement.

In a review of the literature, Byrne (1983) reviewed 30 studies that focused on the relationship between subjectmatter knowledge and student achievement. A slight majority of the studies showed a positive relationship, while the remainder did not. Druva and Anderson (1983) also completed a comprehensive review of the literature available at the time and concluded that there is a positive relationship between teachers' science coursework and student performance, especially for students in higher level courses. Using a slightly different measure of subject-matter knowledge, Strauss and Sawyer (1986) used National Teacher Examination (NTE) scores as an indication of subject-matter knowledge. Specifically, they examined the relationship between district aggregate NTE scores of North Carolina teachers and district-level student performance. Once the researchers controlled for things such as student demographics, they found that teacher scores on the NTE and student performance were strongly and positively associated. They found that as teachers' test scores increased, students' failure rates on high school competency examinations decreased.

Darling-Hammond (2000) found that the percentage of teachers with both a subject matter major and full state certification was positively associated with a state's reading and mathematics scores on the National Assessment of Educational Progress (NAEP). A more recent analysis by Wenglinsky (2000) used multilevel structural equation modeling to analyze data from the NAEP and found that teachers with a major or minor in the subject area that they are assigned to teach produce greater gains in student achievement in both mathematics and science.

The overall findings from these studies suggest that teacher subject-matter knowledge positively influences student achievement. Moreover, this effect seems to be more pronounced for the upper grades than the lower grades. The research, however, is not consistent. Some studies showed no effect for teacher subject-matter knowledge. In addition, the majority of studies focused on mathematics and science teachers

\section{Teachers' Motivation and Performance of Students}

Teachers who spend time preparing lessons and marking homework and class work tend to achieve better result than those who don't (colloids 1989). Government need lift the teachers morale though most cannot afford monetary incentives, but by improving in rewards, career opportunities, initiatives and in service preparations, status and prestige by attracting high quality recruits and retaining talented practitioners in teaching and leadership posts (UNESCO 1994).

But teachers hardly spend any time preparing their lessons, they often don't use schemes of work nor do they keep records of work covered by students. Discipline relies too heavily on punishment. (CASTME International Formal of education development 2001; 361 - 374). Ayot, N.O \& Briggs (1992) studying the role - overload among secondary school teachers in Nairobi found a significant relationship between role - overload and achievements of students. He says that job stress is a major factor in low teacher morale, poor performance, absenteeism and high job turnover. Teachers experiencing job stress have low morale and are not in a position to provide quality teaching. Both Female and male workers in human service fields may experience same amount of stress but do cope differently, Malach and Jackson 1978 cited in Otieno (1997). This calls for the investigation on how much the teacher of mathematics is motivated to participate in subject panels, external examination marking, co-curriculum activities, regular teaching, frequent testing, lesson preparation and remedial teaching which facilitate high achievement in examination and consequently quality outputs.

\section{Findings and Interpretations}

The results are presented in form of tables, frequency counts and percentages. As earlier noted on chapter three of this work, much of this information was provided by both teachers and administrators who included the heads of departments. 


\subsection{Profile of the respondents}

Table 1: Shows the profile of the respondents.

\begin{tabular}{|l|c|c|}
\hline \multicolumn{1}{|c|}{ Respondents } & Frequency & Percentage \\
\hline Sex & & \\
\hline Male & 50 & 56 \\
\hline Female & 40 & 44 \\
\hline Total & 90 & 100 \\
\hline Age & & \\
\hline $19-24$ yrs & 25 & 28 \\
\hline $25-30$ yrs & 35 & 39 \\
\hline 31 and above & 30 & 33 \\
\hline Total & 90 & 100 \\
\hline Academic level & & \\
\hline Certificate & 20 & 22 \\
\hline Diploma & 30 & 33 \\
\hline Degree & 40 & 44 \\
\hline Total & 90 & 100 \\
\hline
\end{tabular}

Source: field data

One hundred questionnaires 100 were distributed to the teachers and 90 were filled and returned. This therefore represents $90 \%$ of the total number of questionnaires that were distributed. The study covered 90 selected teachers and headmasters of whom $50(56 \%)$ were male and $40(44 \%)$ were female. From this statistic, we can see that the difference in sex between the males and females in employment is very low. This could imply that the society of the context of study has empowered women both academically and professionally.

The age category of the respondents was divided in three groups that is 19-24 years were 25 which was (28\%), 25-30 welre $35(39 \%)$ and 31 and above were 30 representing (33\%) of the respondents. Teachers within the age bracket of 25-30 formed the highest percentage at 39 . This could imply that mobility rate is high in the area of study so that older teacher leave teaching for other better paying jobs. The academic level of the respondents was divided in three categories that are certificate, diploma and degree. $20(22 \%)$ of the respondents had certificates, $30(33 \%)$ had diplomas and 40 (44\%) had degrees. From this data we can infer that the area of study is generally empowered academically since most of the teachers are graduate teachers.

\subsection{Determining the level of teacher quality}

The independent variable in this study was teacher quality for which the second objective was directed to determine the level of teacher quality in the sampled school. Teacher quality was broken down into three categories namely; teacher experience, teacher qualification and teacher motivation. Each of the three components was measured by identifying their specific aspects. Teachers were asked to rate the level of agreement with each element by ticking the right box. Responses were likert skaled ranging from 1-5, where 1= very inadequate, 2=inadequate, , 3=fairly adequate, 4=Adequate, 5 Very adequate.

Teachers responses were analyzed using means computed through statistical package for social science and are shown in table three below.

\subsection{Level of teacher quality in kamacharia division}

\begin{tabular}{|l|l|l|}
\hline Types of teacher quality & Mean & Interpretation \\
\hline Teacher Qualification & 3.66 & Adequate \\
\hline Most of you are graduate teachers & $\mathbf{2 . 9 0}$ & Fairly adequate \\
\hline You have embarked on your post graduate studies & $\mathbf{2 . 5 1}$ & Fairly Adequate \\
\hline You have attended pedagogical enhancement courses & $\mathbf{2 . 9 0}$ & Fairly Adequate \\
\hline You participate in setting or marking of national exams & $\mathbf{2 . 4 9}$ & Inadequate \\
\hline Total &
\end{tabular}




\begin{tabular}{|l|l|l|}
\hline Teacher experience & 1.17 & Very inadequate \\
\hline You have taught for more than five years & 2.5 & Fairly Adequate \\
\hline You have enough knowledge on how to handle students & 2.61 & Fairly Adequate \\
\hline You have mastered the syllabus content over the years & 2.85 & Fairly Adequate \\
\hline You can tell learner characteristics that are pro and against sucess & 2.39 & Fairly Adequate \\
\hline You can predict the performance of your learners in the national exams & 2.97 & Fairly Adequate \\
\hline You have taught in many different schools & 2.77 & Fairly Adequate \\
\hline Total & \multicolumn{2}{l|}{} \\
\hline Teacher Motivation & 3.46 & Fairly Adequate \\
\hline You prefer being transferred on promotion & 3.40 & Fairly Adequate \\
\hline Promotion should be based on experience & 3.46 & Fairly Adequate \\
\hline You think that teachers should be paid depending on experience & 2.32 & Fairly Adequate \\
\hline the salary you earn enough for you & 3.48 & Fairly Adequate \\
\hline Increasing teacher's salary can improve their performance & 2.08 & Low \\
\hline you se goals for yourself and achieve them & 2.75 & Fairly adequate \\
\hline Your earn other allowances apart from your salary & 2.60 & Fairly adequate \\
\hline Your work environment is conducive & 3.36 & Fairly Adequate \\
\hline You are granted paternity/ maternity leave & 1.90 & inadequate \\
\hline Your student load is reasonable & 2.90 & Fairly Adequate \\
\hline You have the support of the entire staff in doing your job & 3.36 & Fairly Adequate \\
\hline Your suervisors appreciate the effort you invest in teaching & 2.98 & Fairly Adequate \\
\hline Total & 2.56 & Fairly Adequate \\
\hline Overall total &
\end{tabular}

\section{Source: field data}

Results in table 3 indicate that the respondents agreed that teacher quality in the sampled schools was rather fairly adequate. This is indicated by the fact that most of the ratings are $=3$ which falls under fairly adequate in the likert scale. For example, level of teacher qualification in the table can be said to be in adequate ( a total mean index of 2.49) the same almost applies to teacher experience ( total mean index of 2.77). Teacher motivation in the sampled schools was on average found to be fairly adequate too (mean=2.98).

Although the total mean index for all the three aspects of teacher quality showed fairly adequate levels, some aspects of teacher quality were found very inadequate for example the table reveals that most of the respondents had not taught for more than 5 years with a mean of (1.97), the teaching load was also found to be quite un bearable with a mean of (1.90), the teachers also revealed that they hardly set goals and achieve them. It is also evident that salaries these teachers earn was also rated as very low with a mean of (2.32). The only aspect of teacher quality with the highest rating was the aspect of teacher qualification especially the fact that most of them were graduate teachers. This had a mean of (3.66) could be because the government of Kenya basically employ graduate teachers in secondary schools.

Those aspects of teacher quality that were found out to be fairly adequate in clued; the fact that most of them had embarked on their post graduate studies, a mean of 2.90 , most of them had attended pedagogical enhancement courses a mean of 2.51, they also participate in setting or marking of national exams with a mean of 2.90. as concerns teacher experience, most of those aspects that had a fairly adequate standing include; the fact that they had knowledge on how to handle students (mean 2.5), they had mastered the syllabus content over the years (2.61) they could tell learners characteristics that are pro and against success (2.39), they could predict learners performance in the national exams (2.39) and finally, they had taught in many different schools (2.97)

In respect to teacher motivation, the aspects that scored fairly adequate include the fact that they preffer being transferred on promotion (3.46), Promotion should be based on experience (3.40), You think that teachers should be paid depending on experience (3.46), the salary you earn enough for you (2.32) Increasing teacher's salary can improve their performance (3.48), Your earn other allowances apart from your salary (2. 75), Your work environment is conducive (2.60) , You are granted paternity/ maternity leave (3.36), You have the support of the entire staff in doing your job (2.90) Your supervisors appreciate the effort you invest in teaching (3.36)

Though the general picture potrays fairly adequate level of teacher quality, it is crucial to look at individual aspects because some aspects are thought of as more crucial than others and so their low levels may negatively impact on the teaching learning process. For example, if the teacher is over loaded say at a mean of (1.90) like the tabl3 indicates, then quality may be compromised. So the school administration has to seek for measures to mitigate such shortages either by 
employing more teachers or by creating alternative learning shifts. Could be because of work over load, teachers fail to meet the goals they set in school (mean 2.08) this further reiterates the importance of sufficient staff if school activities are to run smoothly.

\subsection{Teacher Productivity}

The dependent variable of the study was teacher productivity, conceptualized in terms of students' academic achievement which was measured in terms of students' scores ranked as excellent ( $80 \%$ and above), very good (70-79), good (60-69), fairly good (50-59), poor (40-49) and very poor (below 40). Teachers were requested to indicate the number of students who passed in each score rank in the table, their answers were summerised using means as indicated in table 4 below.;

Table 4: students' academic achievement

\begin{tabular}{|c|c|c|}
\hline Range of marks $\%$ & Description & Mean \\
\hline 80 and above & Excellent & 3.52 \\
\hline $70-79$ & Very good & 5.53 \\
\hline $60-69$ & Good & 9.85 \\
\hline $50-59$ & Fairly good & 18.58 \\
\hline $40-49$ & Poor & 29.66 \\
\hline Below 40 & Very Poor & 21.18 \\
\hline Total & & \\
\hline
\end{tabular}

Results from the table 4 above indicate that most students in the sampled schools performed poorly. This is so evident in the above table where most students scored within the rank of 40-49 and below. For example, on average, 30 students scored between 40-49 and 21 scored below 40\% while only four students in each school scored 80 and above, only6 scored between 70-79 and only 10 students scored between 60-69. This points to the fact that the level of teacher productivity interms of student academic achievement was generally poor. On average, only 39 students scored above average (50 and above) while over 50 students in each school sampled scored below average (below 50\%), indicating that on average, the general students' academic achievement in the sampled schools was reported to be generally very low hence the need to understand the cause.

\subsection{The relationship between the level of teacher quality and teacher productivity}

The purpose of this study was to establish whether there was a significant relationship between the level of quality of a teacher and level teacher productivity measured in terms of students' academic performance. Teacher quality was categorized into three aspects namely; teacher qualification, teacher experience and teacher motivation. The adequacy of these aspects in each category was measured using means as shown in Table 4. In an attempt to determine whether there was a significant relationship between the two variables, the researcher used linear correlation coefficient to correlate the mean indices of the three aspects of motivation . results on this test are shown on table 5 below.

Table 5: Relationship between level of teacher quality and teacher productivity

\begin{tabular}{|c|c|c|c|c|}
\hline Variables correlated & r' value $^{\prime}$ & Sig-value & Interpretation of correlation & Decision on Ho \\
\hline Qualification Vs productivity & 0.544 & 0.000 & Significant & Rejected \\
\hline Experience Vs Productivity & 0.543 & 0.000 & Significant & Rejected \\
\hline Motivation Vs Productivity & 0.593 & 0.000 & Significant & Rejected \\
\hline
\end{tabular}

The r' values in the table 5 indicate a positive relationship on the relationship between all aspects of teacher quality and teacher productivity (r-'value $>0$ ), suggesting that the higher the teacher quality, the higher the productivity and vise versa. Considering the fact that all the sign. Values, in table 5, indicate a significant correlation between the two variables, ( Sig. Values< 0.05 ) it is thus sufficient to base on these facts and declare thus all null hypotheses are rejected leading to a conclusion that teacher quality significantly affect teacher productivity measured in terms of students' academic 
performance. This further implies that the higher the teacher qualification in terms of teacher experience, teacher qualification and teacher motivation, the higher will be their productivity and vice- versa.

The results further indicate that of all the teacher quality aspects, teacher motivation was found to be more significant contributor to wards teacher productivity contributing over $60 \%$ towards variations in teacher productivity $\left(r^{\prime}=0.593\right.$, sig. $\left.=0.000\right)$. teacher motivation includes, salaries they are paid, other infringed benefits and allowances, promotion and so on. This may be true because inspite of all other factors, if a teacher is poorly motivated then even his qualification and experience may not do much. So the inadequacy of teacher motivation is likely to affect all other aspects of teacher quality there by escalating the effect the teacher quality may have on teacher productivity.

$59 \%$ of respondents are of the view that more experienced teachers tend to learn better techniques of teaching different subjects and hence their students tend to get better results as a result of that. On the other hand $54 \%$ of the respondents are of the view that experienced teachers tend to command more respect from students and so their students tend to pay more attention to what is being taught. This gets manifested in the results they get which tend to be better than for those students who pay less attention to their teachers. More still, $51 \%$ the respondents are of the view that the more experienced the teacher is the more likely his/her students will pass exams. However respondents did not agree with the view that experienced teachers tend to encourage weak students do better in exams with $57 \%$ of the in total disagreement with the statement. Only $34 \%$ of the respondents were in agreement with the statement.

The findings are in line with those of Thias and Carnoy (1972) in Kenya who showed that teacher experience is better predictor of examination performance than is the formal qualification of the teaching staff. They however hasten to add that this may not be due to the accumulated years of experience but probably due to the respect accorded to the older from the young generation in African societies and the fact that senior staffs are rarely transferred compared to the younger staffs.

Alexander and Simmon (1980) say that experience is more associated with achievement of students only at the Secondary level and further research is necessitated. Conducting this production function with teacher variables will enable me to discover the best combination of teacher characteristics (input) that can be functionally associated with performance (output).

\section{Conclusions}

Basing on the above findings, the following conclusions were made;

The findings revealed that there are more male teachers than female ones on kamacharia Division secondary schools. Majority of the teachers in kamacharia division are youth between the ages of 25-30 and majority are graduate teachers. The re is generally low levels of teacher experience among the secondary school teachers in this Division while motivation and teacher experience are fairly adequate. Teacher productivity interms of students' academic scores is still very low in the division since most of the students in the division still score below average.

Teacher quality interms of teacher qualification significantly affects students' academic achievement, so an increase in teacher qualification by I \% is likely to improve students' academic achievement by $54 \%$ and a decrease in teacher qualification will lower students' academic achievement by $54 \%$

Teacher experience also significantly affects students' academic performance so an increase in teachers' experience by one percent is likely to increase a students' academic performance by $54 \%$ and a decrease in teacher experience by one percent will reduce a students' academic performance by $54 \%$

Finally teacher motivation in qualitative and quantitative terms by one percent will positively increase learners academic percent by $60 \%$ while a reduction in motivation of teachers by $1 \%$ may subsequently lead to students' academic drop by $60 \%$

The study findings point to the fact that teachers should have high mastery of subject content by going through formal education, which is beyond the level of his students (Psacharopolous 1985) this is supported by Caillods (1989) who found teachers with more post secondary education to achieve more with their students than teachers with less post secondary education. According to Alexander \& Simmon, (1980) The teacher is therefore a central input in the school system whose role on determining achievement needs investigation. Teacher certification and academic qualification are particularly important at upper secondary level.

Teachers should have high mastery of subject content by going through formal education, which is beyond the level of his students (Psacharopolous 1985) this is supported by Caillods (1989) who found teachers with more post secondary education to achieve more with their students than teachers with less post secondary education.

According to Alexander \& Simmon, (1980) The teacher is therefore a central input in the school system whose role on determining achievement needs investigation. Teacher certification and academic qualification are particularly 
important at upper secondary level.

The findings revealed that the respondents were in agreement with the following statements; Different subjects teachers who get better pay tend to put in more effort in teaching to see to it that students pass different subjects, Different subjects teachers with a good transport facilitation are in position to come to school every day with out fail to see to it that students is attended to for better performance in exams, Different subjects teachers with good housing facilitation are always available for students in case of revision for better results in exams and lastly Good working environment like offices and spacious classes encourage teachers to work harder towards better results for students.

Finally, the findings of the study in as far as the testing of the hypothesis was concerned showed that there is a significant relationship between Teacher quality and academic performance of students in secondary schools in Kamacharia division, a fact that is not supported by literature according to Gal, et al (1996) who found zero correlation between teacher qualification and students examination scores in Kenya, Egypt and Paraguay. Psacharopoulus (1985) also points out that students do almost as well when studying under untrained teacher as they do when studying under trained graduate from University.

Jones (1997) further disagrees in his study of the effect of trained and untrained teacher in classroom performance in Barbadoes and established that trained teachers do not have advantage over untrained teachers in classrooms performance. Therefore the need to confirm the effect of training on students achievement which will help the government to justify the huge expenditure on teachers training. The past studies stress education on qualification but even after achieving almost $100 \%$ teacher training for secondary level, the achievement in mathematics has remained low deteriorated to the detriments of girls However, the study found out that teacher experience, Qualification, pay and attitude towards the learners had a positive effect on the students' academic achievements revealed that the respondents were in agreement with the following statements; The experience of the teacher and how likely his/her students will pass exams. The experience of the teachers and how they tend to learn better techniques of teaching different subjects and hence their students get better results, the experience of teachers and how it helps to command more respect from students and so students tend to pay more attention and hence perform better, and Experience of teachers and how it tends to encourage weak students do better in exams.

\section{References}

Ayot, N.O \& Briggs (1992) Economics of the Education. Nairobi, Educational Research and Publication.

Beeby, C E (1966), The quality of Education in developing Countries. Massachussets, Harvard University Press.

Best, J.W.\&Khan,J.V. (1993) Research in Education. (7 $7^{\text {th }}$ ed.)NJ;Prentice-Hall.

Blaug, M (1968) Economics of Educations I London; Penguin Books

Blaug, M (1968) Economics of Education. London: Pengiun Books Limited.

Caillods, F (1989), The prospects for Education Planning. IIEP. Paris UNESCO.

Coombs, P.H (1984), The world crisis in education. The view from the eighties. New York, Oxford University Press.

Charles, C. M (1995) Introduction to Educational Research. London, Longman

Creswell, J.W (2003) Research Design; Qualitative, Quantitative and Mixed methods approaches (2nd Ed.)London, Sage.

Eshiwani, a.s (1986) A studies of women's access to higher Education in Kenya

Goldhaber, D.D., \& Brewer, D. J. (1997). Evaluating the Effect of Teacher Degree Level on Educational Performance. In W.J. Fowler (Ed.), Developments in School Finance, Washington, D.C.: National Center for Education Statistics.

Gal, et al (1996) Educational research. An Introduction (6 $6^{\text {th }}$ Edition) Longman.

Cullen, R. (1994). Incorporating a Language Improvement Component in Teacher Training Programmes. ELT Journal, 48(2), 162-172.

Al-Mutawa, N. \& Kailani, T. (1989). Methods of Teaching English to Arab Students. Harlow: Longman

Guthric J.W (1970) A survey of school effectiveness. In do Teachers make a difference? Washington D.C Department of health, Education and Welfare.

Harbison, F \& Myers C (1964) Education, manpower and economic growth. Strategies of Human Resources development. New York, Mc Grow Nill Book Company.

Hopkins, D. (1997) powerful learning, powerful school. London Chapman.

Lafayette, R. C. (1993). Subject Matter Content: What Every Foreign Language Teacher Needs to Know. In G. Gunterman (Ed.), Developing Language Teachers for a Changing World, Chicago: National Text Book Company.

Kyriacou, C 1975) School Teacher Association Study. Chicago University of Chicago Press. Limited.

Norris, I(199)Evaluation, economies and performance Indicators. In J. Ellist (Ed). Reconstructing teacher education London, Farmer Press

Moore, G.W (1983) Developing and evaluating education Research. Boston Colorado University. Little Brown Company.

Psacharopolons G \& Woodhalla, M (1985) Education for development; an analysis of investment Choice New York: Oxford University Press.

SahaL.J (1983) School structures and teacher effects on Academic achievements. A comparative Analysis. In comparative education 
review

National League of Nursing (NLN) Website lead article "Great Moments in Teaching" spring (2007)

Wamahiu, S.P \& Mwiria, K.A (1995), Qualitative research in Education in Issues in Education in Africa. Nairobi, east Africa Educational Publishers.

Republic of Kenya (1995) Report of the third teacher education Conference (Njoro). The quality teacher for The $21^{\text {st }}$ Century and beyond Nairobi. Jomo Kenyatta Foundation.

Republic of Kenya(1999).Kisumu District Development Plan, (2002 - 2008), Nairobi Government Printer.

Repulic of Kenya(2002) National Development Plan 2002 - 2008. Nairobi. Government Printer.

Republic of Kenya(2005).Economic Survey 2005 Nairobi, Government Printer

Ojwang J.A (1995) A study of quality of education in private Secondary schools in Siaya and Kisumu Districts. Unpublished M.Phil Thesis, Moi University, Kenya.

Otieno, K (1997) The relationship of role overload, Locus of Control, years of teaching experience and Gender to perceived burn out among sec. School teachers in Nairobi. Unpublished M.E.D thesis, Kenyatta University. 
